\title{
PERAN JAM BELAJAR EFEKTIF SISWA DI SEKOLAH DALAM MEMODERATORI MOTIVASI DALAM MENINGKATKAN HASIL BELAJAR SISWA
}

\author{
Darius Imanuel W \\ iimanuel10_ewa@yahoo.co.id \\ Magister Manajemen Pendidikan, UKSW
}

\begin{abstract}
The Role Of School Effective Learning Hours In Moderating Students Motivation

To Improving Learning Achievement
\end{abstract}

\begin{abstract}
Motivation is the mean or a process that can be used to affect someone in a positive way so that it can motivate a person to achieve learning outcomes. Learning hours is the time needed to do learning activities well in school. In this study, researcher was interested to know the effect of motivation on learning outcomes moderated by students' effective hours in the school. Without motivation, the learning process will be difficult to be succesfully achieved. This quantitative research was conducted as a case study in high school science students. The study aimed to show an effective model for achieving better student learning outcomes. There were 32 high school science students who became sampled in this study. The data were collected through questionnaire and students' test results. The result was processed and looking for the average by using SPSS. From the SPSS analysis, it was found that the learning motivation was valid and reliable with the value 0.775 and 0.795. Then, it is concludede that motivation model using students' effective hours as a moderator can improve students' learning outcomes in schools.
\end{abstract}

Keywords: Motivation, Effective Hours, and Student Learning Achievement

\section{PENDAHULUAN}

Motivasi dan jam efektif siswa adalah dua faktor yang dapat meningkatkan hasil belajar siswa. Motivasi yang positif adalah masukan-masukan yang baik bagi seseorang sehingga mendorong orang menjadi lebih semangat untuk melakukan sesuatu. Motivasi mampu mendorong orang untuk melakukan sesuatu dalam hal belajar dan dari motivasi orang dapat menentukan baik-tidaknya dalam mencapai tujuan sehingga semakin besar kesuksesean belajarnya (Hamdani 2011:142). Jam efektif adalah waktu yang dipakai untuk beraktifitas atau belajar dengan maksimal. Jika waktu yang ada di sekolah di manfaatkan untuk belajar yang sungguh-sungguh maka hasil belajar siswa akan baik dan prestasi belajar siswa akan menjadi meningkat jika waktu itu benar-benar di manfaatkan.

Penelitian tentang hubungan motivasi dengan hasil belajar dan pengaruh motivasi dengan hasil belajar sudah banyak diteliti. Dari hasil penelitian yang telah di lakukan menjelaskan bahwa motivasi merupakan salah satu faktor yang dapat meningkatkan hasil belajar.Dalam penelitian Rokhimah, Siti (2013) ada pengaruh yang signifikan antara motifasi belajar dengan prestasi belajar siswa. Selain itu juga penelitian dari Pekik, Wicaksono (2016)yang membuktikan bahwa ada pengaruh yang positif antara motivasi belajar dengan prestasi belaja siswa. Oleh karena itu motivasi belajar merupakan faktor yang penting karena hal tersebut merupakan keadaan yang mendorong 
keadaan siswa untuk melakukan belajar sehingga prestasi belajar siswa dapat meningkat (Hamdani 2011:142).

Dari sekian banyak penilitian yang ada baru mencari hubungan dan pengaruh motivasi terhadap hasil belajar atau prestasi belajar siswa,. Namun penelitian tentang efektifnya metode motivasi belajar dimana jam efektif siswa di sekolah sebagai moderator dalam mencapai hasil belajar siswa, masih belum menemukan penelitian yang menyangkut efektifitas motivasi belajar dengan jam efektif siswa di sekolah sebagai moderator dalam mencapai hasil belajar siswa. Oleh karena itu peneliti tertarik melakukan penelitian ini dengan tujuan mau melihat manakah yang efektif apakah dengan metode motivasi belajar dimana jam efektif siswa di sekolah dijadikan sebagai moderator dalam mencapai hasil belajar siswa dibandingkan dengan metode motivasi belajar tanpa moderator terhadap hasil belajar.

\section{KAJIAN PUSTAKA}

\section{Manajemen Pendidikan}

Manajemen pendidikan adalah seni dan ilmu mengelola sumber daya pendidikan untuk mewujudkan proses dan hasil belajar peserta didik secara aktif, kreatif, inovatif, dan menyenangkan dalam mengembangkan potensi dirinya (Usman, Husaini 2013:13). Bush (2008) menyatakan bahwa manajemen pendidikan harus terpusat pada tujuan pendidikan. Tujuan ini memberikan arti penting terhadap arah manajemen. Manajemen diarahkan pada pencapaian tujuan pendidikan tertentu dalam waktu tertentu.

Tujuan dan manfaat manajemen pendidikan diungkapakan oleh Usman (2013) ada 8, yaitu: (1) terwujudnya suasana belajar dan proses Pembelajaran yang Aktif, Kreatif, Efektif, Menyenangkan, dan Bermakna (PAKEMB); (2) terciptanya peserta didik yang aktif mengembangkan potensi dirinya; (3) Terpenuhinya salah satu dari lima kompetensi tenaga kependidikan (tertuangnya kompetensi manajerial tenaga kependidikan sebagai manajer); (4) tercapainya tujaun pendidikan secara efektif dan efisien; (5) terbekalinya tenaga kependidikan degan teori tentang proses dan tugas administrasi pendidikan (tertunjangnya profesi sebagai manajer atau konsultan manajemen pendidikan); (6) teratasinya masalah mutu pendidikan karena $80 \%$ masalah mutu disebabkan oleh manajemennya; (7) terciptanya perencanaan pendidikan yang merata, bermutu relevan, tidak bias jender dan SARA, dan akuntabel; (8) tercipta citra positif pendidikan.

\section{Manajemen Sekolah}

Manajemen sekolah merupakan proses atau kegiatan yang terstruktur yang dilakukan disekolah dimana kegiatan ini melibatkan stakeholder sekolah dengan tujuan agar program sekolah dapat berjalan secara efektif dan efisien (Usman, Husaini 2013)

Manajemen sekolah merupakan faktor yang paling penting dalam menyelenggarakan pendidikan dan pengajaran di sekolah yang keberhasilannya diukur oleh prestasi yang didapat, oleh karena itu dalam menjalankan kepemimpinan, harus menggunakan suatu sistem, artinya dalam penyelenggaraan pendidikan di sekolah yang di dalamnya terdapat komponen-komponen terkait seperti guru-guru, staff TU, orang tua siswa, masyarakat, pemerintah, anak didik, dan lain-lain harus berfungsi optimal yang dipengaruhi oleh kebijakan dan kinerja pimpinan.

\section{Motivasi Belajar}

Pada dasarnya motivasi adalah suatu usaha yang disadari untuk menggerakkan, mengarahkan dan menjaga tingkah laku seseorang agar ia terdorong untuk bertindak melakukan sesuatu sehingga mencapai hasil atau tujuan tertentu.

Menurut Clayton Alderfer (dalam Nashar, 2004:42) Motivasi belajar adalah kecenderungan siswa dalam melakukan kegiatan belajar yang didorong oleh hasrat untuk mencapai prestasi atau hasil belajar sebaik mungkin. Motivasi dipandang sebagai dorongan mental yang menggerakkan dan mengarahkan perilaku manusia, termasuk perilaku belajar. Dalam motivasi terkandung adanya 
Peran Jam Belajar Efektif Siswa di sekolah dalam Memoderatori Motivasi dalam Meningkatkan Hasil Belajar Siswa (Darius Imanuel W)

keinginan yang mengaktifkan, menggerakkan, menyalurkan dan mengarahkan sikap serta perilaku pada individu belajar (Koeswara, 1989 ; Siagia, 1989 ; Sehein, 1991; Biggs dan Tefler, 1987 dalam Dimyati danMudjiono, 2006)Untuk peningkatan motivasi belajar menurutAbin Syamsudin M (1996) yang dapat kita lakukanadalah mengidentifikasi beberapa indikatornyadalam tahap-tahap tertentu. Indikator motivasiantara lain: 1) Durasi kegiatan, 2) Frekuensikegiatan, 3) Presistensinya pada tujuan kegiatan,4) Ketabahan, keuletan dan kemampuannya dalammenghadapi kegiatan dan kesulitan untuk mencapaitujuan, 5) Pengabdian dan pengorbanan untukmencapai tujuan, 6) Tingkatan aspirasi yang hendakdicapai dengan kegiatan yang dilakukan, 7) Tingkatkualifikasi prestasi, 8) Arah sikapnya terhadapsasaran kegiatan.

\section{Jam Efektif Siswa Di Sekolah}

Jam efektif siswa merupakan waktu yang dibutuhkan siswa untuk melaksanakan proses belajar yang dilakukan di kelas dengan tujuan agar siswa lebih banyak belajar dibandingkan waktu untuk bermain.

Waktu merupakan sesuatu yang penting dalam kehidupan manusia. Waktu juga merupakan kesempatan yang digunakan untuk melakukan berbagai macam kegiatan. Adapun yang dimaksud dengan waktu belajar adalah waktu yang digunakan untuk mempelajari sesuatu, sehingga terjadi proses perubahanpadadiri seseorang yang belajar.

Jadi, waktu efektif belajar adalah waktu yang digunakan untuk mempelajari sesuatu, sehinggaterjadi perubahan pada diri seseorang yang belajar. Waktu belajar adalah waktu yang terjadinya proses belajar siswa di sekolah, baik pagi, siang, maupun sore haribergantung pada jadwal yang sudah ditetapkan oleh pihak sekolah. Oleh karenaitu, penentuan waktu belajar di sekolah yang tepatakan memberi pengaruh positif terhadap prestasi belajar siswa.

\section{HasilBelajar}

Hasil belajar siswa di kelas menentukan prestasi siswa di sekolah. Dari hasil-hasil yang diperoleh yaitu dari ulangan harian atau tes-tes kecil yang dilakukan dikelas dapat dijadikan data kognitif siswa yang diakumulasi untuk menentukan prestasi siswa disekolah dimana akumulasi data kogitif ini ditentukan oleh guru mata pelajaran. Menurut Winarno Surakhmad (dalam buku, Interaksi Belajar Mengajar, (Bandung: Jemmars, 1980:25) hasil belajar siswa bagi kebanyakan orang berarti ulangan, ujian atau tes. Maksud ulangan tersebut ialah untuk memperoleh suatu indek dalam menentukan keberhasilan siswa.

Dalam kelas interaksi antara guru dengan siswa merupakan proses mentransfer ilmu atau pengetahuan dari guru ke siswa dengan tujuan menambah wawasan dan intelektual siswa secara langsung. Sehingga hasil belajar siswa merupakan kemampuan siswa setelah melakukan interaksi dengan guru dikelas. Dimyati dan Mudjiono (2006: 3-4) juga menyebutkanhasil belajar merupakan hasil dari suatu interaksi tindak belajar dantindak mengajar. Oleh karena itu siswa yang mampu mendapat hasil yang baik di kelas menunjukan bahwa guru sudah mampu mentrasfer ilmu atau pengetahuannya kepada siswa dalam kondisi normal.

Dari hasil-hasil yang diperoleh siswa di kelas kemudian akan di akumulasi menjadi nilai atau indeks prestasi siswa di sekolah tersebut apakah siswa tersebut layak untuk masuk kejenjang yang lebih tinggi dari sebelumnya.

Kata prestasi berasal dari bahasa Belanda yaitu prestatie, sedangkan dalam bahasa Inggris istilah prestasi atau achievement dalam Kamus Lengkap Psikologi (Kartini Kartono \& Dali Gulo, 2006) didefinisikan sebagai pencapaian atau hasil yang dicapai; sesuatu yang telah dicapai; satu tingkat khusus dari kesuksesan karena mempelajari tugas-tugas, atau tingkat tertentu dari kecakapan/ keahlian dalam tugas-tugas sekolah atau akademis; satu tingkat khusus perolehan atau hasil keahlian dalam karya akademis yang dinilai oleh guru-guru lewat tes-tes yang dibakukan, atau lewat kombinasi kedua hal tersebut. Dalam kamus populer dinyatakan bahwa: prestasi adalah apa yang telah 
diciptakan, hasil pekerjaan, hasil yang menyenangkan hati yang diperoleh dengan jalan keuletan kerja. Sedangkan dalam kamus bahasa Indonesia bahwa: prestasi adalah hasil yang telah dicapai (dan yang telah dilakukan atau dikerjakan).

Poerwanto (2007) memberikan pengertian prestasi belajar yaitu " hasil yangdicapai oleh seseorang dalam usaha belajar sebagaimana yang dinyatakan dalam raport". Selanjutnya Winkel (1997) mengatakan bahwa "prestasi belajar adalah suatu bukti keberhasilan belajar atau kemampuan seseorang siswa dalam melakukan kegiatan belajar sesuai dengan bobot yang dicapainya" Sedangkan menurut Nasution, S (1987) prestasi belajar adalah " kesempurnaan yang dicapai seseorang dalam berfikir, merasa dan berbuat, prestasi belajar dikatakan sempurna apabila memenuhi tiga aspek yakni: kognitif, afektif dan psikomotor, sebaliknya dikatakan prestasi kurang memuaskan jika seseorang belum mampu memenuhi target dalam ketiga kriteria tersebut" Berdasarkan pengertian diatas, maka dapat dijelaskan bahwa prestasi belajar merupakan tingkat kemanusiaan yang dimiliki siswa dalam menerima, menolak dan menilai informasi-informasi yang diperoleh dalam proses belajar mengajar. Prestasi belajar seseorang sesuai dengan tingkat keberhasilan sesuatu dalam mempelajari materi pelajaran yang dinyatakan dalam bentuk nilai atau raport setiap bidang studi setelah mengalami prosesbelajar mengajar. Prestasi belajar siswa dapat diketahui setelah diadakan evaluasi. Hasil dari evaluasi dapat memperlihatkan tentang tinggi atau rendahnya prestasi belajar siswa.

\section{METODE}

Penelitian ini bertujuan utuk mencari pengaruh motivasi terhadap hasil belajar dengan jam efektif siswa di sekolah sebagai moderator ini menggunakan metode penelitiankuantitatif yang dilaksanakan di kelas2 IPA SMA, sampel sebanyak 32 orang siswa dan dilakukanselama 4 bulan dari bulan Agustus sampai denganNovember 2015. Variabel independen dalampenelitian ini yaitu motivasi belajar dan jam belajar efektif siswa di sekolah. Motivasi terdapat 8indikator sebagaimana yang diungkapkan oleh AbinSyamsudin M (2007:30) kemudian disusun dalambentuk instrumen angket dengan jumlah20 soal. Sedangkan jam efektif siswa di sekolah hanya sebatas moderator. Angket ini terlebih dahulu diuji validitas danreliabilitas sebelum dipakai di lapangan. Sedangkanvariabel dependen yaitu nilai tes formatif matapelajaran matematika yang berasal dari data dokumentasirata-rata prestasi belajar siswa dalam pembelajaran.

Setelah itu dilakukan uji regresi linearberdasarkan hipotesis: "semakin rendah motivasi yang diberikan dan jam efektif siswa tidak ditambah maka hasil belajar siswa pada mata pelajaran matematikasemakin menurun". Atau sebaliknya "semakin tinggi motivasi yang diberikan dan jam efektif siswa ditambah maka hasil belajar siswa pada mata pelajaran matematikasemakin meningkat". Analisis dilakukan terhadap semua data yang diperoleh dengan bantuan programSPSS Statistik.

\section{HASIL DAN PEMBAHASAN}

\section{Deskripsi Hasil Penelitian}

Setalah melakukan penilitian kelas dua IPA di SMA dengan jumlah siswa 32 siswadan hasil analisis terhadap hasil rata-rata angketdari total jumlah siswa menunjukan valid, reliabeldan terdistribusi normal. Kemudian di peroleh data angket dari soal motivasi yang dibagikan diperoleh rata-rata minimum 53 dan tertinggi 72, nilai rata-rata keseluruhan siswa adalah 60,31 dengan standar deviasi 5,10. Untuk jam efektif siswa yang diberikan di sekolah minimal 5 jam dan maksimumnya 10 jam, rata-rata jam efektifnya adalah 8 jam dengan standar deviasi 2,03. Sedangkan hasil matematika yang diperoleh minimum 65 dan yang memperoleh nilai tertinggi 85 dengan rata-rata keseluruhan siswa adalah 71,94, dan standar deviasi 4,62. Berikut adalah tabel deskripsi statistiknya. 
Peran Jam Belajar Efektif Siswa di sekolah dalam Memoderatori Motivasi dalam Meningkatkan Hasil Belajar Siswa (Darius Imanuel W)

Tabel 1 Descriptive Statistics

\begin{tabular}{|c|c|c|c|c|c|}
\hline & $\mathrm{N}$ & Minimum & Maximum & Mean & Std. Deviation \\
\hline motivasi & 32 & 53.00 & 72.00 & 60.3125 & 5.10179 \\
\hline jam_efektif & 32 & 5.00 & 10.00 & 8.0000 & 2.03200 \\
\hline hasil_math & 32 & 65.00 & 80.00 & 71.9375 & 4.62069 \\
\hline Valid N (listwise) & 32 & & & & \\
\hline
\end{tabular}

Tabel 2 Model Summary

\begin{tabular}{lrrrr}
\hline Model & R & R Square & $\begin{array}{c}\text { Adjusted R } \\
\text { Square }\end{array}$ & $\begin{array}{c}\text { Std. Error of the } \\
\text { Estimate }\end{array}$ \\
\hline 1 & $.529^{\mathrm{a}}$ & .280 & .203 & 4.12545 \\
\hline a. Predictors: (Constant), M, motivasi, jam_efektif
\end{tabular}

Tabel 3 ANOVA ${ }^{\mathrm{a}}$

\begin{tabular}{llrrrrrr}
\hline Model & & Sum of Squares & df & Mean Square & F & \multicolumn{1}{c}{ Sig. } \\
\hline 1 & Regression & 185.334 & 3 & 61.778 & 3.630 & $.025^{\mathrm{b}}$ \\
\cline { 2 - 8 } & Residual & 476.541 & 28 & 17.019 & & \\
\cline { 2 - 7 } & Total & 661.875 & 31 & & & \\
\hline
\end{tabular}

a. Dependent Variable: hasil_math

b. Predictors: (Constant), M, motivasi, jam_efektif

Dari tabel model summary (Tabel 2) diperoleh nilai koefisien determinasi 0,203 artinya hasil belajar siswa dapat di pengaruhi oleh motivasi, jam efektif siswa, dan variable moderator sebesar 20,3\% dan sisanya yaitu 79,7\% variable lain di luar model. Pada tabel ANOVA (Tabel 3) didapat data hasil uji signifikansi uji $\mathrm{F}$ dimana nilai uji $\mathrm{F}$ adalah 3,63 dengan probabilitas $0,025<(0,05)$.

Tabel 4 Coefficients ${ }^{\mathrm{a}}$

\begin{tabular}{|c|c|c|c|c|c|c|}
\hline \multirow{2}{*}{\multicolumn{2}{|c|}{ Model }} & \multicolumn{2}{|c|}{ Unstandardized Coefficients } & $\begin{array}{l}\text { Standardized } \\
\text { Coefficients }\end{array}$ & \multirow[b]{2}{*}{$\mathrm{t}$} & \multirow[b]{2}{*}{ Sig. } \\
\hline & & $\mathrm{B}$ & Std. Error & Beta & & \\
\hline 1 & (Constant) & -96.709 & 68.779 & & -1.406 & .171 \\
\hline & motivasi & 3.013 & 1.218 & 3.327 & 2.474 & .020 \\
\hline & $\overline{\text { jam_efektif }}$ & 14.897 & 7.317 & 6.551 & 2.036 & .051 \\
\hline & $\bar{M}$ & -.270 & .128 & -8.984 & -2.109 & .044 \\
\hline
\end{tabular}

a. Dependent Variable: hasil_math

Hasil Uji model parsial (uji t) memperlihatkan bahwa motivasi memberikan nilai koefisienparameter sebesar 3,013 dengan sig 0,020. Variabel jam efektif siswa memberikan nilaikoefisien sebesar 14,89 dengan sig 0,051, sementara variabel moderator (M) memberikan nilai koefisiensebesar negative $(0,270)$ dengan sig 0,044 . Kesimpulan yang bisa diperoleh dari hasil di atas adalah Moderator terbukti signifikan dalammempengaruhi motivasi terhadap hasil belajar siswa. Prediksi nilai negativemengindikasikan bahwa efek moderasi yang diberikan adalah negative, artinya jam efektif siswa memberi efek mengurangi pengaruh motivasi terhadap hasil belajar siswa. Tidak signifikannya koefisien jam efektif siswa (sig 0,051) menunjukkan bahwa variabel ini merupakan variabel moderator murni dan tidak bisa ditempatkan sebagai variabelindependen. Namun jika hasil menunjukkan bahwa jam efektif siswadan moderator sama-sama signifikan maka dapat disimpulkan 
bahwa variabel jam efektif siswa adalahvariabel quasi moderator atau dapat digunakan sebagai variabel independen sekaligusvariabel moderator.

\section{Pembahasan}

Setalah membuktikan bahwa soal angket motivasi yang digunakan valid dan reliabel, peneliti langsung melakukan tahap pembagian soal-soal angket motivasi dengan jumlah 20 soal kepada 32 siswa kelas dua IPA. Kemudian diperoleh data dan peniliti melakukan analisis statistik dengan menggunakan SPSS dimana maksimum rata-rata dari siswa yang menjawab adalah 72 dan nilai ratarata terendah adalah 53. Setelah itu masuk ketahap mencari nilai koefisien determinasi yang diperoleh dengan bantuan SPSS sebasar 0,203, atau dalam presentase sebesar 20,3\%, ini menunjukan bahwa motivasi, jam efektif siswa di sekolah dan varibel moderator dengan presentase 20,3\% dapat mempengaruhi hasil belajar siswa di sekolah. Sedangkan sisanya adalah faktor-faktor lain yang juga dapat mempengaruhi hasil belajar tetapi di luar model penelitian dengan presentase $79,7 \%$. Uji $\mathrm{F}$ menunjukan bahwa model ini signifikan dimana signifikansinya sebesar $(0,025)<(0,05)$, artinya dapat mempengaruhi atau meningkatkan hasil belajar siswa melalui motivasi, jam efektif siswa, dan variable moderator.

Dari tabel 4 diperoleh signifikansi dari motivasi sebesar $(0,020)$, signifikansi dari jam efektif siswa sebesar $(0,051)$, dan signifikansi dari moderator sebesar $(0,044)$. Kesimpulan yang bisa diperoleh dari hasil ini adalah moderator terbukti signifikan dalammempengaruhi motivasi terhadap hasil belajar siswa. Artinya motivasi punya pengaruh yang sigifikan terhadap hasil belajar siswa. Sehingga sebagaimana yangdiungkapkan oleh Keller (dalam Nashar, 2004:77)bahwa prestasi belajar dapat dilihat dari terjadinyaperubahan hasil masukan pribadi berupa motivasidan harapan untuk berhasil. Peningkatan hasilbelajar siswa dipengaruhi oleh banyak faktor salahsatunya adalah motivasi untuk belajar.Hasil penelitian ini juga menginformasikanterdapat pengaruh yang signifikan antara motivasiyang menggunaka jam efektif siswa sebagai moderator terhadap hasil belajar siswa. Hal ini berartibahwa semakin tinggi motivasi yang diberikan dan jam efektif siswa ditambah maka hasil belajar siswa meningkat.Sebaliknya semakin rendah motivasi yang diberikan dan jam efektif siswa tidak ditambah maka hasil belajar siswa menurun.

\section{SIMPULAN DAN SARAN}

\section{Simpulan}

Dari hasil penelitian dapat disimpulkan bahwa motivasi dapat mempengaruhi hasil belajar siswa melalui variable moderator jam efektifitas siswa di sekolah, jika dilahat dari uji $\mathrm{F}$ nilai signifikannya sebesar $0,025<0,050$. Selain itu jam efektifitas tidak dapat dijadikan sebagai variable independen jika dilihat dari hasil penelitian diperoleh signifikansinya 0,051 artinya jam efektif siswa di sekolah murni sebagai variable moderator murni.

\section{Saran}

Untuk guru lebih ditingkat cara memotivasi anak didik di sekolah agar siswa menjadi lebih sadar dan kemauan belajar lebih tinggi. Semoga dengan penelitian ini dapat mampu merubah mainset guru-guru yang masih menggunakan pola lama yaitu memarahi anak, tetapi dirubah dengan kalimat memotivasi anak. Tujuannya agar anak tidak patah semangat untuk belajar.Selain itu dengan program pemerintah yang menerapkan full day scholl dapat membuka wawasan pembaca khususnya orang tua bahwa dengan penambahan jam belajar anak di sekolah lebih lama maka anak lebih banyak belajar disekolah dibanding menghabiskan waktu bermain dirumah. Faktor ini juga mampu meningkatkan prestasi belajar siswa disekolah. Dengan catatan program yang dijalankan harus benar diawasi oleh guru, karena orangtua kedua siswa adalah guru selain orantua di rumah siswa.Itu saran dari penulis semoga bermanfaat bagi pembaca dan membuka wawasan pembaca sesuai harapan penulis. 
Peran Jam Belajar Efektif Siswa di sekolah dalam Memoderatori Motivasi dalam Meningkatkan Hasil Belajar Siswa (Darius Imanuel W)

\section{DAFTAR PUSTAKA}

Arikunto, Suharsimi. 2009. Dasar-Dasar Evaluasi Pendidikan (edisi revisi). Jakarta: PT Bumi Aksara

Budiyono. 2009. Statistik Untuk Penelitian edisi ke-2. Surakarta: Sebelas Maret University Press. Hamdani. 2011. Strategi Belajar Mengajar. Bandung: CV. Pustaka Setia

Pekik, Wicaksono (2016) Pengaruh Fasilitas Belajar, Motivasi Belajar Dan Minat Belajar Terhadap Prestasi Belajar Siswa Kelas X Smk Muhammadiyah Prambanan Tahun Ajaran 2011/2012. S1 Thesis, U N Y.

Rokhimah, Siti (2013). Pengaruh Perhatian Orang Tua Dan Motivasi Belajar Terhadap Prestasi Belajar Akuntansi Siswa Kelas Xi Akuntansi Smk Ypkk 2 Sleman Tahun Ajaran 2012/2013. S1 Thesis, Fakultas Ekonomi UNY.

Tirtarahardja \& Sulo. 2005. Pengantar Pendidikan. Jakarta: Rineka Cipta Trihendradi, C. 2013.Langkah Mudah Menguasai SPSS 21. Yogyakarta: Andi Yogyakarta Usman, Husaini. 2013. Manajemen (teori, praktik, dan Riset Pendidikan).Jakarta: Bumi Aksara. 